Vol. 9, No. 1, pp. 31-38, April 2021

PEDAGOGI: JURNAL PENDIDIKAN DASAR

http://jurnal.fkip.unila.ac.id/index.php/pgsd

\title{
Hubungan Motivasi Belajar Ekstrinsik dan Disiplin Belajar dengan Hasil Belajar Matematika Peserta Didik di Sekolah Dasar
}

\author{
Eni Septiani 1 $1^{1}$, Erni $2^{2}$, Amrina Izzatika $3^{3}$ \\ ${ }^{1}$ FKIP, Universitas Lampung \\ ${ }^{2}$ FKIP, Universitas Lampung \\ ${ }^{3}$ FKIP, Universitas Lampung \\ Email: eniseptiani1799@gmail.com
}

\begin{abstract}
The problem with this study is low mathematics learning outcomes of students. This study aimed to determine a relationship between learning extrinsic motivation and mathematics learning outcomes, relationship between learning discipline and mathematics learning outcomes, and relationshiop between learning extrinsic motivation and learning discipline to mathematics learning outcomes of students grade V at SD Negeri 4 Sumberejo. This type of research is quantitative by an ex-postfacto correlation research method. The population in this study is 55 students. Sample retrieval techniques used a total sampling. Data collection techniques was used in the form of questionnaires and documentation. Data analysis techniques using statistical tests of multiple correlation. Research shows that there is a significant reationship between learning extrinsic motivation and learning discipline with the mathematics learning outcomes of students grade $V$ at SD Negeri 4 Sumberejo with a coefficient correlation of 0,501 positive with "moderate" criteria.
\end{abstract}

Keywords: learning extrinsic motivation, learning discipline, mathematics learning outcomes

\begin{abstract}
Abstrak: Masalah dalam penelitian ini adalah rendahnya hasil belajar matematika peserta didik. Penelitian ini bertujuan untuk mengetahui hubungan antara motivasi belajar ekstrinsik dan hasil belajar matematika, hubungan antara disiplin belajar dan hasil belajar matematika dan hubungan antara motivasi belajar ekstrinsik dan disiplin belajar secara bersama-sama dengan hasil belajar matematika peserta didik kelas V di SD Negeri 4 Sumberejo. Jenis penelitian ini yaitu kuantitatif dengan metode penelitian ex-post facto korelasi. Populasi dalam penelitian ini sebanyak 55 peserta didik. Teknik pengambilan sampel menggunakan total sampling. Pengumpulan data yang digunakan berupa angket dan dokumentasi. Teknik analisis data menggunakan uji statistik korelasi ganda. Hasil penelitian menunjukkan adanya hubungan yang signifikan antara motivasi belajar ekstrinsik dan disiplin belajar dengan hasil belajar matematika kelas V peserta didik di SD Negeri 4 Sumberejo dengan koefisien korelasi sebesar 0,501 bertanda positif dengan kriteria "sedang".
\end{abstract}

Kata kunci : motivasi belajar ekstrinsik, disiplin belajar, hasil belajar matematika 


\section{PENDAHULUAN}

Pendidikan merupakan usaha manusia untuk mendapatkan pengetahuan, baik dalam segi nilai, sikap, kepribadian, dan keterampilan. Pendidikan menjadi proses perubahan diri seorang individu dalam rangka meningkatkan kualitas hidup manusia. Pendidikan juga menjadi wadah untuk mengembangkan potensi diri yang dimiliki untuk siap bersaing di masa depan.

Dalam suatu lembaga pendidikan, bentuk keberhasilan belajar peserta didik dapat dilihat dari tercapainya hasil belajarnya. Keberhasilan dalam belajar peserta didik ditandai dengan pemerolehan hasil belajar yang optimal. Hasil belajar peserta didik yang optimal dipengaruhi oleh dua faktor yaitu faktor internal yang berasal dari dalam peserta didik, misalnya disiplin belajar, kondisi fisiologis (keadaan fisik dari peserta didik), kondisi psikologis (kecerdasan, bakat, minat, motivasi) dan faktor eksternal yang berasal dari luar diri peserta didik, misalnya faktor lingkungan (keluarga, sekolah dan masyarakat) alat instrumen (kurikulum, metode pembelajaran, sarana dan prasarana belajar serta pendidik).

Berdasarkan hasil observasi awal yang dilakukan pada bulan Desember 2020 di SD Negeri 4 Sumberejo Bandar Lampung. Peneliti melakukan wawancara dengan pendidik dengan berpedoman pada indikator yang digunakan terkait motivasi belajar ekstrinsik yang diperoleh peserta didik dari orang tuanya dan kesadaran disiplin belajar pada diri peserta didik di masa pandemi COVID-19 seperti ini. Peneliti mendapatkan hasil keseluruhan bahwa $60 \%$ peserta didik kurang diberikan motivasi belajar dari orang tua dan sebanyak $56 \%$ peserta didik belum memiliki kesadaran disiplin dalam belajar.

Menurut Sardiman (2016: 90-91), "motivasi belajar ekstrinsik adalah motif-motif yang aktif dan berfungsinya karena adanya perangsang dari luar." Motivasi belajar ekstrinsik yang paling dekat dan dibutuhkan oleh peserta didik berasal dari lingkungan keluarga yang dalam hal ini adalah motivasi orang tua. Orang tua turut memberikan andil cukup besar dalam meningkatkan motivasi belajar peserta didik. Dukungan motivasi dari orang tua dapat memunculkan keinginan peserta didik untuk berusaha dan melakukan yang terbaik.

Selanjutnya berkaitan dengan faktor intrinsik, menurut Slameto (2013:2), "disiplin belajar merupakan suatu proses perubahan yang diperoleh dari usaha yang dilakukan seseorang untuk memperoleh suatu perubahan tingkah laku yang baru secara keseluruhan, sebagai hasil pengalamannya sendiri dalam interaksi dengan lingkungannya." 
Disiplin belajar dalam penelitian ini menggunakan beberapa indikator yang dikemukakan oleh Arikunto (2010: 137) yaitu:

1. Perilaku kedisiplinan di dalam kelas

2. Perilaku kedisiplinan di luar kelas, di lingkungan sekolah

3. Perilaku kedisiplinan di rumah.

Menurut pendapat Susanto (2013: 5), "hasil belajar adalah perubahanperubahan yang terjadi pada diri peserta didik, baik yang menyangkut aspek kognitif, afektif dan psikomotor sebagai hasil dari kegiatan belajar." Prinsip dalam penilaian hasil belajar peserta didik dari Bloom dalam Sulistiasih (2018: 6-8) membagi hasil belajar menjadi tiga ranah yaitu:

a. Ranah kognitif, domain ini memiliki enam jenjang kemampuan yaitu pengetahuan, pemahaman, penerapanan.

b. Ranah afektif, berkenaan dengan sikap yang terdiri dari lima aspek, yakni penerimaan, jawaban atau reaksi, penelitian, organisasi, dan internalisasi.

c. Ranah psikomotorik, berkenaan dengan hasil belajar keterampilan dan kemampuan bertindak. Ada enam aspek ranah psikomotorik, yakni gerakan refleks, keterampilan gerakan dasar, kemampuan perseptual, keharmonisan atau ketepatan, gerakan keterampilan kompleks, dan gerakan ekspresif dan interpretatif.

Penelitian ini difokuskan pada pembelajaran matematika dalam segi kognitif. Menurut Susanto (2013 : 184), matematika merupakan salah satu disiplin ilmu yang dapat meningkatkan kemampuan berpikir dan berargumentasi, memberikan kontribusi dalam penyelesaian masalah sehari-hari dan dalam dunia kerja serta memberikan dukungan dalam pengembangan ilmu pengetahuan dan teknologi.

Penelitian ini akan menelaah pada faktor ekstrinsik yaitu motivasi belajar dari orang tua dan faktor intrinsik yaitu disiplin belajar peserta didik yang berpengaruh pada peningkatan hasil belajar peserta didik. Kedua faktor tersebut cukup berkaitan dalam rangka tercapainya hasil belajar yang diinginkan, khususnya pada pembelajaran matematika. Penelitian ini bertujuan untuk mengetahui apakah terdapat hubungan motivasi belajar ekstrinsik dan disiplin belajar dengan hasil belajar matematika peserta didik di SD Negeri 4 Sumberejo Bandar Lampung. 


\section{METODE}

Jenis penelitian dalam skripsi ini adalah penelitian kuantitatif. Metode dalam penelitian ini yaitu ex-post facto untuk meneliti peristiwa yang telah terjadi. Sugiyono (2017: 7) mengemukakan bahwa "Penelitian ex-post facto adalah suatu penelitian yang dilakukan untuk meneliti peristiwa yang telah terjadi dan kemudian melihat ke belakang untuk mengetahui faktor-faktor yang dapat menimbulkan kejadian tersebut."

Penelitian ini dilaksanakan pada tahun ajaran 2020/2021 di kelas V SD Negeri 4 Sumberejo Bandar Lampung. Dikarenakan pandemi COVID-19 yang masih merebak di Indonesia, penelitian ini tidak dapat terlaksana dengan maksimal.

Populasi dalam penelitian ini adalah peserta didik kelas V di SD Negeri 4 Sumberejo yang berjumlah 55 peserta didik. Penelitian ini menggunakan teknik total sampling sehingga seluruh peserta didik turut andil dalam proses penelitian.

Teknik pengumpulan data yang digunakan yaitu angket dan dokumentasi. Variabel dalam penelitian terdiri dari variabel bebas yaitu motivasi belajar ekstrinsik $\left(\mathrm{X}_{1}\right)$ dan disiplin belajar $\left(\mathrm{X}_{2}\right)$, sedangkan variabel terikat yaitu hasil belajar matematika peserta $\operatorname{didik}(\mathrm{Y})$.

Teknik analisis data untuk mengetahui hubungan antar variabel $\mathrm{X}$ dengan variabel $\mathrm{Y}$ menggunakan rumus uji korelasi product moment dan untuk mengetahui hubungan variabel $\mathrm{X}_{1}, \mathrm{X}_{2}$, dan $\mathrm{Y}$ menggunakan rumus multiple correlation dengan kriteria pengujian jika $t_{\text {hitung }}>t_{\text {tabel }}$ maka $\mathrm{H}_{\mathrm{o}}$ ditolak dan $\mathrm{H}_{\mathrm{a}}$ diterima dan jika $t_{\text {hitung }}<t_{\text {tabel }}$ maka $\mathrm{H}_{\mathrm{o}}$ diterima dan $\mathrm{H}_{\mathrm{a}}$ ditolak dengan mengambil taraf signifikansi $5 \%$.

\section{HASIL DAN PEMBAHASAN}

Penelitian ini diawali dengan observasi pada bulan Desember 2020 di SD Negeri 4 Sumberejo. Setelah mendapatkan data penelitian pendahuluan, peneliti membuat instrumen penelitian berupa angket untuk mendapatkan data. Setelah itu, angket tersebut diuji cobakan dengan 20 peserta didik kelas VA SDN 1 Pinang Jaya pada tanggal 1 April 2021. Peneliti membagikan angket melalui Google Form kepada responden.

Penelitian dilaksanakan dengan menyebarkan angket motivasi belajar ekstrinsik dan disiplin belajar secara serentak kepada responden sebanyak 55 peserta didik. Pengumpulan data dilaksanakan di SD Negeri 4 Sumberejo Bandar 
Lampung pada tanggal 20 April 2021 di kelas VA dan VB. Angket dikerjakan peserta didik di rumah masing-masing dikarenakan kondisi saat ini yang sedang pandemi, kemudian dikumpulkan kembali pada tanggal 27 April 2021. Pengambilan data dilakukan sebanyak satu kali kepada seluruh populasi dalam penelitian.

Berdasarkan hasil perhitungan uji hipotesis I menggunakan rumus korelasi product moment didapatkan bahwa korelasi antara $\mathrm{X}_{1}$ dan $\mathrm{Y}$ sebesar 0,280 bertanda positif dengan kriteria rendah. Kontribusi variabel $\mathrm{X}_{1}$ terhadap variabel $\mathrm{Y}$ sebesar 7,84\%. Hal ini berarti $\mathrm{Ha}$ diterima dan $\mathrm{H}_{\mathrm{o}}$ ditolak yaitu terdapat hubungan positif dan signifikan antara motivasi belajar ekstrinsik dengan hasil belajar matematika peserta didik kelas V SD Negeri 4 Sumberejo.

Berdasarkan hasil perhitungan uji hipotesis II menggunakan rumus korelasi product moment didapatkan bahwa koefisien korelasi antara $\mathrm{X}_{2}$ dan variabel $\mathrm{Y}$ sebesar 0,463 bertanda positif dengan kriteria sedang. Kontribusi variabel $\mathrm{X}_{2}$ terhadap variabel $\mathrm{Y}$ sebesar $21,44 \%$. Hal ini berarti Ha diterima dan $\mathrm{H}_{\mathrm{o}}$ ditolak yaitu terdapat hubungan positif dan signifikan antara disiplin belajar dengan hasil belajar matematika peserta didik kelas V SD Negeri 4 Sumberejo.

Perhitungan uji hipotesis III menggunakan rumus multiple correlation. Namun, sebelumnya hubungan antara $X_{1}$ dan $X_{2}$ harus diketahui terlebih dahulu. Berdasarkan hasil perhitungan hubungan $\mathrm{X}_{1}$ dan $\mathrm{X}_{2}$ diperoleh hasil koefisien korelasi antara variabel $\mathrm{X}_{1}$ dan $\mathrm{X}_{2}$ sebesar 0,194 bertanda positif. Setelah itu, mencari hubungan antara $\mathrm{X}_{1}$ dan $\mathrm{X}_{2}$ dengan variabel $\mathrm{Y}$. Berdasarkan hasil perhitungan uji hipotesis ketiga dalam penelitian ini diperoleh hasil koefisien korelasi antara $\mathrm{X}_{1}$ dan $\mathrm{X}_{2}$ dengan variabel $\mathrm{Y}$ sebesar 0,501 bertanda positif dengan kriteria sedang. Kontribusi variabel X1 dan X2 terhadap variabel Y sebesar $25,10 \%$ sedangkan $74,90 \%$ dipengaruhi oleh faktor lain di luar penelitian. Nilai kebermaknaan (signifikan) sebesar $=8,71>\mathrm{F}_{\text {tabel }}=3,18$ berarti signifikan. Hal ini berarti $\mathrm{Ha}$ diterima dan $\mathrm{H}_{\mathrm{o}}$ ditolak yaitu terdapat hubungan yang signifikan antara motivasi belajar ekstrinsik dan disiplin belajar dengan hasil belajar matematika peserta didik kelas V SD Negeri 4 Sumberejo.

Motivasi belajar ekstrinsik dari orang tua sangat dibutuhkan untuk perkembangan belajar seorang anak. Motivasi belajar dari orang tua yang diterima peserta didik berguna untuk meningkatkan kemauannya dan kesadarannya dalam belajar, serta menjadikan peserta didik merasa didukung dalam hal belajar. Pentingnya pemberian motivasi belajar ekstrinsik dapat membangkitkan minat dan keinginan peserta didik untuk terus berproses dalam mendapatkan hasil 
belajar yang terbaik karena memiliki rasa bahwa segala sesuatunya didukung oleh orang tua.

Hal ini sesuai dengan penelitian yang dilakukan oleh Yuni Lutfiana (2015) yang menunjukan adanya hubungan positif motivasi belajar dengan disiplin belajar peserta didik kelas IV dan V SD Muhammadiyah 7 Joyosuran tahun ajaran 2014/2015 dan sesuai dengan rumusan hipotesis yang diajukan yaitu ada hubungan yang signifikan antara motivasi belajar ekstrinsik dan disiplin belajar peserta didik kelas V di SD Negeri 4 Sumberejo.

Dari penjabaran tersebut maka motivasi belajar ekstrinsik dari orang tua menjadi salah satu faktor yang memengaruhi hasil belajar. Sehingga variabel antara motivasi belajar ekstrinsik dan hasil belajar saling berhubungan.

Seperti yang dikemukakan Aulina (2013: 37), "Melalui disiplin anak dapat belajar berperilaku sesuai dengan cara yang disetujui dan sebagai imbalannya mereka dapat dengan mudah diterima oleh lingkungan sosialnya." Disiplin menjadikan segala sesuatunya menjadi teratur dan tertata sesuai dengan rencana yang telah dibuat. Disiplin belajar menjadikan peserta didik patuh terhadap segala bentuk peraturan dan menjadikan dirinya memiliki kontrol diri sepenuhnya ingin seperti apa cara ia belajar dan bagaimana cara ia menerima pembelajaran.

Hal ini sesuai dengan penelitian yang dilakukan oleh Manazila (2017) yang menunjukkan bahwa terdapat hubungan yang positif, kuat, dan signifikan antara motivasi belajar dan disiplin belajar secara bersama-sama dengan hasil belajar kelas V di SD Negeri Gugus Watubarut Kebumen dan sesuai dengan hipotesis yang diajukan yaitu ada hubungan yang positif dan signifikan antara motivasi belajar ekstrinsik dan disiplin belajar peserta didik kelas V SD Negeri 4 Sumberejo.

Berbicara tentang disiplin belajar tidak lepas kaitannya dengan motivasi belajar. Hal ini diperkuat dengan hasil penelitian dari Jeffrey \& Zein (2017: 15471) bahwa: "The three independent variables of achievement motivation, learning discipline and learning facilities have positive significant influences on student learning outcome." Pernyataan tersebut dapat diartikan yaitu "Tiga variabel bebas dari motivasi yang dicapai, disiplin belajar, dan fasilitas belajar memiliki hubungan yang signifikan terhadap hasil belajar peserta didik." Oleh karena itu, pemberian motivasi belajar dari orang tua yang bersifat kuat dapat menumbuhkan kesadaran disiplin belajar bagi peserta didik untuk mencapai hasil belajar yang maksimal. Kembali lagi peran orang tua cukup penting dalam pembentukan jiwa disiplin belajar dan senantiasa memantau perkembangan hasil belajar peserta didik. 
Hasil belajar adalah suatu perolehan kemampuan yang didapat peserta didik setelah mengikuti proses pembelajaran, yang ditandai dengan perubahan baik dari kognitif, afektif, dan psikomotor. Hasil belajar yang ditekankan dalam penelitian ini yaitu hasil belajar matematika dalam ranah kognitif.

Jadi, motivasi belajar ekstrinsik merupakan dorongan untuk melakukan aktivitas belajar untuk mencapai tujuan, motivasi belajar ekstrinsik yang kuat dari orang tua menjadikan peserta didik memiliki minat untuk terus belajar dan meningkatkan hasil belajar. Begitu pula dengan adanya disiplin belajar yang mengakar kuat dalam diri peserta didik maka terbentuklah pengendalian diri yang baik. Berdasarkan hal tersebut, dapat diketahui bahwa terdapat hubungan yang signifikan antara motivasi belajar ekstrinsik dan disiplin belajar dengan hasil belajar matematika peserta didik kelas V SD Negeri 4 Sumberejo.

\section{KESIMPULAN}

Berdasarkan data hasil penelitian dan pembahasan diperoleh kesimpulan bahwa terdapat hubungan yang positif dan signifikan motivasi belajar ekstrinsik dan disiplin belajar dengan hasil belajar matematika peserta didik kelas V di SD Negeri 4 Sumberejo. Hal tersebut berarti Ha dalam penelitian ini diterima, yang meliputi:

1. Terdapat hubungan yang signifikan antara motivasi belajar ekstrinsik dengan hasil belajar matematika peserta didik kelas V di SD Negeri 4 Sumberejo.

2. Terdapat hubungan yang signifikan antara disiplin belajar dengan hasil belajar matematika peserta didik kelas V di SD Negeri 4 Sumberejo.

3. Terdapat hubungan yang signifikan antara motivasi belajar ekstrinsik dan disiplin belajar secara bersama-sama dengan hasil belajar matematika peserta didik kelas V di SD Negeri 4 Sumberejo.

\section{DAFTAR PUSTAKA}

Arikunto, Suharsimi. 2010. Dasar-dasar Evaluasi Pendidikan. Bumi Aksara, Jakarta.

Aulina, C. N. 2013. Penanaman Disiplin Pada Anak Usia Dini. PEDAGOGIA: Jurnal Pendidikan. 2: 36-49.

Jeffrey, I., \& Zein, A. 2017. The Effects of Achievement Motivation, Learning Discipline and Learning Facilities on Student Learning Outcomes. International Journal of Development Research. 7: 1547115478. 
Manazila, A. 2017. Hubungan Motivasi Belajar dan Disiplin Siswa dengan Hasil Belajar PKn Kelas V. Joyful Learning Journal. 6: 61-70.

Sardiman. 2016. Interaksi dan Motivasi Belajar Mengajar. PT Grafindo Persada, Jakarta.

Slameto. 2013. Belajar dan Faktor-faktor yang Mempengaruhinya. PT Rineka Cipta, Jakarta.

Sugiyono. 2017. Metode Penelitian Kuantitatif, Kualitatif, dan R\&D. Alfabeta, Bandung.

Sulistiasih. 2018. Evaluasi dan Asesmen Pembelajaran SD. Graha Ilmu, Yogyakarta.

Susanto, Ahmad. 2013. Teori Pembelajaran di SD. Kencana Prenada Media Group, Jakarta.

2013. Teori Belajar dan Pembelajaran di Sekolah Dasar. PT. Fajar Interpratama Mandiri, Jakarta.

Yuni Lutfiana, D. I. A. N. 2015. Hubungan Motivasi Belajar dengan Disiplin Belajar Siswa Kelas IV Dan V SD Muhammadiyah 7 Joyosuran Kecamatan Pasar Kliwon Kota Surakarta Tahun Ajaran 2014/2015 (Doctoral dissertation, Universitas Muhammadiyah Surakarta). 